\title{
IMPLEMENTATION OF EXPERIENTAL LEARNING MODELS TO IMPROVE REASONING ABILITY OF STUDENT'S SMP
}

\author{
Antik Vinayanti ${ }^{1}$, Fika Muji Fadhillah ${ }^{2}$ \\ ${ }^{1,2}$ Mathematics Education Program Post Graduate IKIP Siliwangi, Cimahi \\ avinayanti@gmail.com $^{1}$, fadhillah fika@yahoo.com ${ }^{2}$
}

Received: Apr 4 ${ }^{\text {th }}, 2019 ;$ Accepted: May 20 ${ }^{\text {th }}, 2019$

\begin{abstract}
Abstrak
Experimental learning invites students to play an active role during the learning process based on life experiences that can be applied into four stages, namely concrete experience, observation, conceptualization and application. This study aims to determine the differences and enhancement of mathematical reasoning abilities of students who get learning using the experiential learning method better than conventional learning. The method used in this study is the experimental method by taking the sample of this study is the seventh grade students of SMPN 2 Klangenan Cirebon Regency. Implementation data with an experimental learning model was obtained through observation sheets and students' mathematical reasoning abilities were obtained through description tests. The results of the study for four meetings showed an increase in the average results of the pretest and posttest. From the results of statistical tests of gain scores obtained from the results of the pretest and posttest on students' mathematical reasoning abilities the average ( $\dot{\mathrm{x}}$ ) gain for the experimental class is 0.64 with the standard deviation $(\mathrm{s})=0.6$. Based on these results it can be concluded that students' mathematical reasoning abilities using experiential learning are better than students who are conventional learning.
\end{abstract}

Keywords: Experimental Learning, Reasoning Ability

How to Cite: Vinayanti, Antik \& Fadhillah, Fika Muji. (2019). Implementation of Experiental Learning Models to Improve Reasoning Ability of Student's SMP Negeri 2 Klangenan Cirebon. JIML, 2 (1), 1-8.

\section{INTRODUCTION}

The change of curriculum emphasize the students to be more active in learning process. Curriculum 2013 (Kementerian Pendidikan dan Kebudayaan, 2017; Widiastuti \& Santosa, 2014), Mathematic education at school is expected to give contribution to supporting graduate achievement in primary and secondary education through learning experience. It makes the students able to: (a) understand the math concept and apply the procedure in their daily life. (b) do the mathematical operation to simplify and analyse the components , (c) do mathematical reasoning which covers making generalization based on pattern, fact, phenomenon or existing data. making hypothesis, and verify it; (d) solve the problem and communicate the idea through the symbol, table, diagram, or other medias to clarify the condition and the problem; (e) develop positive attitudes like logical, critical, accurate, carefully, and persistent attitude in solving the problem.

Sumarmo (Hendriana, Rohaeti, \& Sumarmo, 2017) suggests that mathematics learning is directed at providing opportunities for development of reasoning abilities, awareness of the usefulness of mathematics, fostering self-confidence, objective attitude and openness to face an ever-changing future. The statement shows that reasoning is needed to build a 
mathematical idea and to show evidence of the mathematical truth of the idea. Reasoning is a thought process in the process of drawing conclusions (Bernard, 2015). According to Sumarmo (2015) in general there are two types of reasoning, namely inductive and deductive reasoning. Reasoning is a logical way of thinking of students in an inductive approach, namely learning provides logical evidence to reach conclusions and deductive learning, namely concepts of problem solving based on proven mastery of science so students can think logically based on facts to draw conclusions (Haerudin, 2013). The inductive and deductive equation is that both are arguments that have a structure, consisting of several premises and a conclusion or conclusion. The difference is on the basis of drawing conclusions and the nature of conclusions that are derived.

Theoretically, analogy reasoning is very helpful for students in understanding mathematical concepts, one of them is abstract concepts which are then described and analogized to be concrete in mathematics learning (Rahmawati \& Pala, 2014). In addition, this analogy reasoning helps students to acquire new knowledge or concepts and associate previously separate concepts into a whole concept. Then, the things that must be considered in solving problems related to analogy reasoning are first that students must have and master the knowledge or concept of the preconditions related to the material. Thus, students can minimize conceptual errors in their initial knowledge and can identify concepts and process of resolution contained in the problem of the right source to help resolve the target problem.

The low mastery of material influences students' reasoning abilities (Amelia, 2015; Sardin, 2015). Mathematics learning in schools is expected to be able to train students' reasoning so that students are expected to get used to life to develop reasoning skills in solving problems and applying concepts that have been learned in real life (Amelia, 2015; Lanani, 2015; Sariningsih \& Herdiman, 2017; Widiastuti \& Santosa, 2014). To improve students' reasoning abilities in mathematics learning, namely by designing a learning model that involves more active student interaction and is related to the direct experience experienced by students. The saying says that experience is the best teacher (experience is the best teacher), because from experience we can learn. Experiential learning is an approach through experience or learning by experiencing itself (Indrastoeti \& Mahfud, 2015). Fun learning can be done in various ways, one of which is using an experimental learning model. In this case, various activities that have been done by students as life experiences can be used as an interesting activity material. Thus they can show their ability in tangible results.

Learning with experimental learning models was introduced in 1984 by David Kolb. David Kolb defines learning as the process of how knowledge is created through changing forms of experience (Minati, 2017). Learning from experience includes the link between doing and thinking. If students are active in the learning process, students will learn much better. This is because in the learning process students actively think about what is learned and then how to apply what has been learned in real situations. Atherton (Fathurrohman, 2015) suggests that in the context of experience-based learning it can be described as a learning process that reflects experience deeply and from this emerges a new understanding or learning process and transfer of knowledge, skills and attitudes. 
3 Vinayanti \& Fadhillah, Implementation of Experiental Learning Models to Improve Reasoning Ability of Student's SMP Negeri 2 Klangenan Cirebon

Using the experiential learning model will enable a conducive learning atmosphere. This conducive learning atmosphere will facilitate the learning process so that it will be able to improve student learning outcomes. In the experimental learning model, concepts introduced to students through problems, where the problem is a daily problem experienced by students (Alamanda, 2017). In the experiential learning model students are invited to look at events encountered in everyday life and do simple research to find out what really happened then draw conclusions together. This conclusion is one of the understandings achieved by students to be used as a basis in understanding other events related to previous events.

Experiental learning model is a learning model which activate learning process to build the find outledge and the skills throuhout direct experience (M. Sholihah, Utaya, \& Susilo, 2016). This model is succesful is if students are active during the learning process. This model possibly gives good effects to the students because the model is interesting and also challenge students to study so they are motived. Therefore It will influence their learning process. Theresult of the reasch is taken from learning activities which based on their experience, Actually students' observation toward their environment improve their scientific process skills and critical thinking skills more than learning proccess based on practical work.

The reseach result which has been done by D. A. Sholihah \& Mahmudi (2015) tells that experiental learning model is more effective than convetional model in terms of students' apreciation of math and math achievement. David Kolb (D. A. Sholihah \& Mahmudi, 2015) said that there are Six Characteristic of experiental Learning. E xperiental learning has six main Characters, They are:

1. Learning is best understood as a process, not in terms of results. Learning is a process not in terms of results.

2. Learning is an ongoing process based on experience. Learning is an ongoing process based on experience.

3. The learning process requires resolving conflicts between adaptation modes that are dialectically opposed to the world. Learning requires resolution between dialectically diverted styles.

4. Learning is a process of holistic adaptation to the world. Learning is a holistic process.

5. Learning involves transactions between people and the environment. Learning involves relationships between people and the environment.

6. Learning is a process of creating knowledge. Learning is a process of making knowledge.

Based on Kolb's revelation, it can be interpreted that: (1) best learning is understood as a process. Not in relation to the results achieved; (2) learning is a continuous process based on experience; (3) learning requires the resolution of conflicts between styles that are contrary to dialectical ways for adaptation to the world; (4) learning is a holistic process for adaptation to the world; (5) learning involves the relationship between someone and the environment, and (6) learning is a process of creating knowledge.

Basically learning the experiential learning model is simple starting with doing (do), reflecting (reflecting), and then applying. The steps in David Kolb's experiential learning (C, N, \& Ng'eno, 2016) are concrete experience, reflective observation, abstract conceptualization and active experimentation. The four stages can be described in the cycle as follows: 


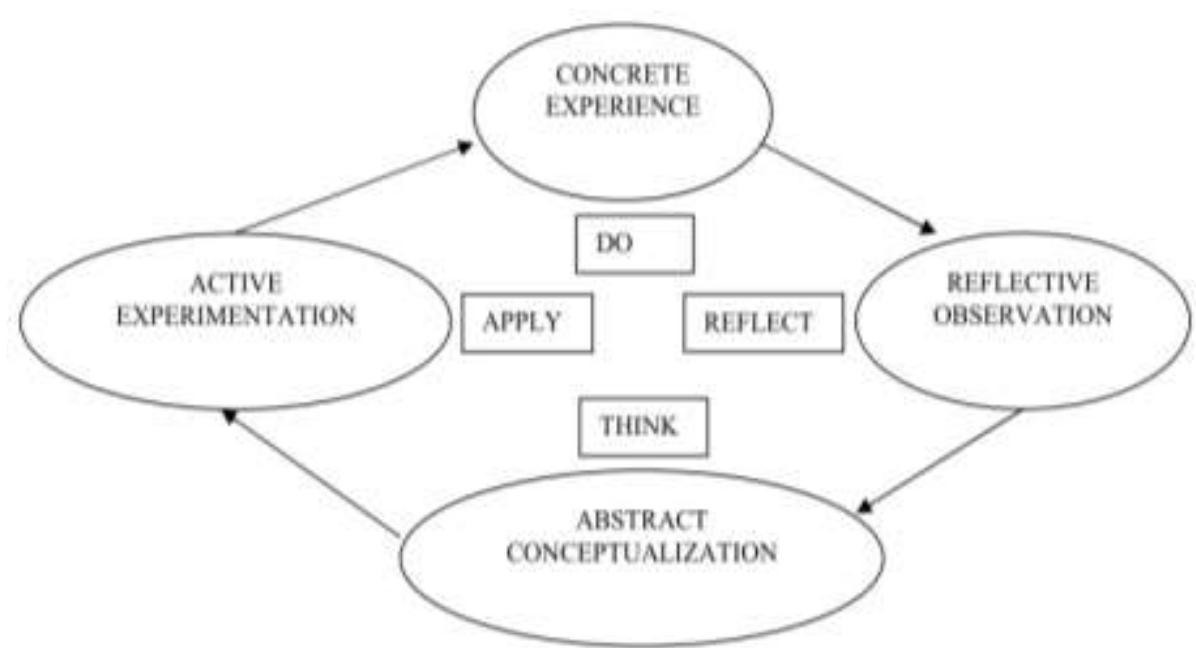

Figure 1. learning activity in experiential learning model

At the stage of concrete experience, learning begins from the college students' concrete experience. In reflective observation,college students observe the experience of their learning activity which is done by using their five sense. in the stage of abstract conceptualization, college students start to find the reason then formulate reciprocal relationship of the experience gained. in implementation, college students plan to test the efficacy of the model or theory to explain the new experiences that will be obtained next (Latipah, 2017).

The experiential learning model has advantages that are (1) Increasing the enthusiasm of students to learn so as to create an active learning atmosphere, conducive and dynamic and open from various directions; (2) Encourage and develop high-level thinking skills because active participatory students find a concept (Indrastoeti \& Mahfud, 2015)

Beside having some advantages, experiental learning model has also some disadvantages, like it takes relatively long time in learning process, Kolb Theory is lso too wide in scope. Therefore This research will review how is the application of experiental learning affect the enhancement of junior high school students' reasoning skills.

\section{METHOD}

The method used in this research is experiment quantitative. The treatment is learning Math with experiental learning model as free variable, the measured aspects are math reasoning skills as dependent variable. quantitative data of the students reasoning skill enhancement are based on gain calculation that is normalized through pre-test and post-test result. Qualitative data analysis is in the form of the teacher and students activities data in every stages of experiental learning model which are taken from the observer's comments in observation sheet.

The research population is all seventh grade students in SMP Negeri 2 Klangenan school year 2018/2019 that consist of eight classes, and The sampling technique used is simple random sampling technique. Sample choosen is class 7B that consist of 40 students. 
5 Vinayanti \& Fadhillah, Implementation of Experiental Learning Models to Improve Reasoning Ability of Student's SMP Negeri 2 Klangenan Cirebon

\section{RESULTS AND DISCUSSION}

\section{RESULT}

Based on the hypothesis test that has been done on the pretest and posttest data of the experimental group and the control group, it was stated that the two groups were normally distributed and homogeneous in the aspects of students' mathematical reasoning. To find out whether there are differences in the average of the two groups of samples, the similarity test for the pretest results is obtained by the results of 0.081 with a significance level of $\alpha=0.05$ so that $\mathrm{H}_{0}$ is accepted. Thus, there is no difference in the average mathematical reasoning ability of experimental class students and the control class.

Next is the calculation to determine the test of the difference in the two average posttest of students' mathematical reasoning abilities.

Table 1. Test of Difference in Two Average Post-Test Data of Experimental Class and

\begin{tabular}{cccccc}
\hline Class & $\mathbf{N}$ & Mean & StDev & Sig (1-tailed) & Interpretation \\
\hline Eksperiment & 40 & 24,3 & 5,3 & 0.0235 & $\mathrm{H}_{0}$ ditolak \\
Control & 40 & 21,9 & 5,0 & & \\
\hline
\end{tabular}

Based on calculations using SPSS, the results of sig (1-tailed) were obtained at the significance level of $0.05=0.0235$ because the significance value was $<0.05$, so Ho rejected. So it was concluded that there were differences in the average posttest scores between the experimental group and the control group.

To determine the increase in mathematical reasoning abilities that have been achieved by students and their qualifications used a normalized gain score (N - Gain). From the results of the t-test calculations that have been done obtained a significance value $=0.003$. With the testing criteria the value of $t$, if the significance is $>0.05$ then $\mathrm{H}_{0}$ accepted and vice versa if the significance is $<0.05$ then $\mathrm{H}_{0}$ rejected.

Based on the testing criteria as listed above, $\mathrm{H}_{0}$ rejected. It can be concluded that the gain of the experimental group is better than the control class.

Table 2. Recapitulation of t-test results against Gain Score

\begin{tabular}{ccccccc}
\hline Class & N & Mean & SD & Sig & Df & Interpretation \\
\hline Eksperiment & 40 & 0.64 & 0.6 & \multirow{2}{*}{0.003} & 78 & $\mathrm{H}_{0}$ rejected \\
Control & 40 & 0.47 & 0.2 & & & \\
\hline
\end{tabular}

\section{Discussion}

The purpose of experiental learning model is to ask students to use their reasoning power to the events that happen in their daily life and to do simple research to understand what really happen then make the conclusion together. Based on the data that has been obtained, it is 
known that experiental learning can improve students' reasoning skill to the topic; two dimentional figure : rectangular and triangle. Overall, all teacher's and students' activities in learning process using experiental learning model run well.

In the first meeting, students and teachers must adapt. Teacher explains about the steps of the experiental learning model. Teacher finds some difficulties in directing the students to find out the knowledge by themselves from their experience, because they are used to study with conventional model, so that the steps of experiental leraning model has not run well yet.

Teacher,in the second step, has been accustomed to condition the class and communicate well with the students. Teacher can implement all the learning steps better than which in the previous meeting. students has known the steps so that teacher does not find any difficulties in every step. It is just not all of the students are active in doing the experiment. in this meeting teacher's and students' activities increase well. in the third meeting the improvement of the students' and teacher's activity can be seen clearly. in this meeting most of students are active. students' enthusiastic happen in active experiment process when almost all students take involve in doing the experiment. in this meeting students are already orderly enough and can be conditioned. Students are accustomed to the model used by the teacher.

In the fourth meeting, the learning steps of experiental learning model become more perfect. in the stage of concrete experience, students are increasingly able to interpret their reasoning skill, students have been able to be given real problems in accordance with their experience that relate with the topic. in reflective observation satage, students can observe and consider their experiences so that they can improve their reasoning dimension. In conceptualization, students can integrate and manipulate their new experiences with their previous ones. The last stage, Active experimentation, Students can implement the knowledge gained in the different situations and make the conclusion, and also give the reason. Thus, experiental learning model can be suporting development of students' math reasoning skill.

The increase in reasoning and learning activities during the four meetings was caused by students 'motivation during the model step, which was active experimentation which made students more enthusiastic in learning and the teacher offered certain awards to increase students' motivation to actively talk during the learning process. In addition, the advantages of the experiential learning model become one of the factors that influence it, where the experiential learning model can help improve students' thinking skills by proving it directly in the learning process. This is in line with the opinion of Hariri \& Yayuk (2018) that the advantages of individual experiential learning models, namely (1) increase awareness of selfconfidence; (2) improve communication, planning and problem solving skills; (3) grow and improve the ability to deal with bad situations; (4) growing and increasing mutual trust among group members; (5) grow and enhance the spirit of cooperation and the ability to compromise; (6) grow and increase commitment and responsibility. The advantages of the group experiential learning model are developing and increasing mutual interdependence between groups and involving involvement in problem solving and decision making. 
7 Vinayanti \& Fadhillah, Implementation of Experiental Learning Models to Improve Reasoning Ability of Student's SMP Negeri 2 Klangenan Cirebon

Deep reasoning will be realized if a learning model is applied that emphasizes the process of building knowledge independently such as the experiential learning model. With the experiential learning model students are invited to directly feel and observe events that are around them by collecting data found so that students are able to report what is found from their experience.

\section{CONCLUSION}

From the analysis of the observation sheet, the implementation of students' and teacher activities during the math learning process on the topic two dimentional figure : rectangular and triangle with experiental learning model in seventh grade SMP Negeri 2 Klangenan Cirebon increase with a very good category.

There is an increase in students' reasoning skills in flat quadrilateral and triangle building material using experiential learning models in class VII SMP Negeri 2 Klangenan Cirebon. Cirebon obtained an average $\mathrm{N}-$ Gain value of 0.055 .

\section{REFERENCES}

Alamanda, G. C. (2017). Penerapan Model Pembelajaran Experiental Learning terhadap Perubahan Konseptual Siswa pada Materi Sifat-Sifat Cahaya. Jurnal Penelitian Pendidikan LPPM Universitas Pendidikan Imdonesia, 17(1), 28-34.

Amelia, R. (2015). Pencapaian Kemampuan Penalaran Matematis Siswa SMP dengan Menggunakan Metode Pembelajaran Inkuiri Terbimbing. Jurnal Ilmiah UPT P2M STKIP Siliwangi, 2(1), 98-105.

Bernard, M. (2015). Meningkatkan Kemampuan Komunikasi dan Penalaran serta Disposisi Matematik Siswa SMK dengan Pendekatan Kontekstual Melalui Game Adobe Flash CS 4.0. Infinity Journal, 4(2), 197-222.

C, C. M., N, G. B., \& Ng'eno, J. K. (2016). Effects of Experiential Learning Approach on Students ' Mathematical Creativity among Secondary School Students of Kericho East Sub-Country, Kenya. Journal of Education and Practice, 7(23), 51-57.

Fathurrohman, M. (2015). Model - model Pembelajaran Inovatif Alternatif Desain Pembelajaran yang Menyenangkan. Yogyakarta: Ar - Ruzz Media.

Haerudin. (2013). Pengaruh Pendekatan SAVI terhadap Kemampuan Komunikasi dan Penalaran Matematik serta Kemandirian Belajar Siswa SMP. Infinity Journal, 2(2), 183193.

Hendriana, H., Rohaeti, E. E., \& Sumarmo, U. (2017). Hard Skills dan Soft Skills Matematik Siswa. Bandung: Reflika Aditama.

Indrastoeti, J., \& Mahfud, H. (2015). Pembelajaran Kooperatif Dengan Pendekatan Experiental Learning Untuk Meningkatkan Keterampilan Sosial. Mimbar Sekolah Dasar, 2(2), 140-151. https://doi.org/10.17509/mimbar-sd.v2i2.1325

Kementerian Pendidikan dan Kebudayaan. (2017). Buku Guru Matematika SMP/MTs Kelas VII Revisi 2017. Jakarta: Kementerian Pendidikan dan Kebudayaan. 
Lanani, K. (2015). Efektivitas Pembelajaran Kooperatif Ditinjau dari Peningkatan Kemampuan Penalaran Logis Matematis Siswa. Infinity Journal, 4(2), 140-151. https://doi.org/10.22460/infinity.v4i2.78

Latipah, E. (2017). Pengaruh Strategi Experiental Learning terhadap Self Regulated Learning Mahasiswa. Jurnal Humanitas, 14(1), 41-56.

Minati, D. F. (2017). Pengaruh Pembelajaran Berdasarkan Pengalaman (Experiental Learning) Terhadap Pengetahuan Prosedural Fisika Ditinjau Dari Gaya Belajar Peserta Didik Kelas $\mathrm{X}$ MA DDI Takkalasi Barru. Jurnal Pendidikan Fisika Universitas Muhammadiyah Makassar, 5(I), 1-14.

Rahmawati, D. I., \& Pala, R. H. (2014). Kemampuan Penalaran Analogi Dalam Pembelajaran Matematika. Jurnal Euclid, 4(2), 717-725.

Sardin, S. (2015). Perbandingan Keefektifan Pembelajaran GI dan Problem Solving Ditinjau dari Prestasi Belajar Peluang, Kemampuan Penalaran, dan Sikap Siswa terhadap Matematika. PYTHAGORAS: Jurnal Pendidikan Matematika, 10(2), 189-200. https://doi.org/10.21831/pg.v10i2.9158

Sariningsih, R., \& Herdiman, I. (2017). Mengembangkan Kemampuan Penalaran Statistik dan Berpikir Kreatif Matematis Mahasiswa melalui Pendekatan Open Ended. Jurnal Riset Pendidikan Matematika, 4(2), 239-246.

Sholihah, D. A., \& Mahmudi, A. (2015). Keefektifan Experiental Learning Pembelajaran Matematika MTs Materi Bangun Ruang Sisi Datar. Jurnal Riset Pendidikan Matematika, 2(2), 175-185.

Sholihah, M., Utaya, S., \& Susilo, S. (2016). Pengaruh Model Experintal Learning terhadap Kemampuan Berpikir Siswa SMA. Jurnal Pendidikan, 1(11), 2096-2100.

Sumarmo, U. (2015). Kumpulan Makalah Berpikir Dan Disposisi Matematik Serta Pembelajaranya. Bandung: Jurusan Pendidikan Matematika FPMIPA UPI Bandung.

Widiastuti, \& Santosa, R. H. (2014). Pengaruh Metode Inkuiri terhadap Ketercapaian Kompetensi Dasar, Rasa Ingin Tahu, dan Kemampuan Penalaran Matematis. PYTHAGORAS: Jurnal Pendidikan Matematika, 9(2), 196-204. 